\title{
Absorption, Translocation and Metabolism of CNP, a Diphenyl Ether Herbicide, and its Amino Derivative in Rice Plants
}

\author{
Hitoshi Shimotori* and Shozo Kuwatsuka \\ Department of Agricultural Chemistry, Nagoya University Nagoya, 464, Japan
}

(Received February 17, 1978)

\begin{abstract}
The absorption, translocation, and metabolism of CNP, a diphenyl ether herbicide, and its amino derivative $\left(\mathrm{CNP}-\mathrm{NH}_{2}\right)$ which is a major degradation product of $\mathrm{CNP}$ in soils were investigated in rice plants, by using ${ }^{14} \mathrm{C}-\mathrm{CNP}$ and ${ }^{14} \mathrm{C}-\mathrm{CNP}-\mathrm{NH}_{2}$ labeled uniformly at the nitro- and amino- phenyl rings, respectively. CNP and $\mathrm{CNP}-\mathrm{NH}_{2}$ were absorbed rapidly through the roots, but were hardly translocated to the foliage, especially in $\mathrm{CNP}-\mathrm{NH}_{2}$. The amounts of $\mathrm{CNP}$ and $\mathrm{CNP}-\mathrm{NH}_{2}$ absorbed from soil culture were far less than those absorbed from water culture. CNP was scarcely metabolized in the rice plant, while $\mathrm{CNP}-\mathrm{NH}_{2}$ was rapidly metabolized.

The metabolism of CNP in the rice plant gave rise to three major metabolites, and two of them were identified as 2,4,6-trichlorophenyl $4^{\prime}$-formylaminophenyl ether and 2,4,6-trichlorophenyl 4'-hydroxyphenyl ether. $\mathrm{CNP}-\mathrm{NH}_{2}$ and its $\mathrm{N}-$ glucoside were also detected. $\mathrm{CNP}-\mathrm{NH}_{2}$ absorbed by the rice plant from water culture decreased rapidly and produced two major metabolites and a number of minor ones.
\end{abstract}

\section{INTRODUCTION}

CNP (MO ${ }^{\circledR}, 2,4,6$-trichlorophenyl 4'-nitrophenyl ether) is widely used as a preemergence herbicide for controlling various weeds in rice (Oryza sativa L.) cultivation in Japan. Several researches have been conducted on the abosrption and metabolism of diphenyl ether herbicides in plants. For example, nitrofen $(3,4$ dichlorophenyl $p$-nitrophenyl ether $)^{1)}$, fluorodifen ( $p$-nitrophenyl $\alpha, \alpha, \alpha$-trifluoro-2-nitro$p$-tolyl ether $)^{2,3)}$ and chlomethoxynil (2,4dichlorophenyl $3^{\prime}$-methoxy - 4' - nitrophenyl ether $)^{4)}$ were absorbed by plants, but their translocation in plants was limited. Cleavage of the ether linkage and reduction of the nitro substituent occurred in plants, ${ }^{2,3)}$ but chlomethoxynil provided no phenolic derivatives in plants. ${ }^{4)}$

\footnotetext{
* Visiting researcher from Agricultural Research Laboratory, Mitsui Toatsu Chemicals Inc., 500 Nishikubo, Chigasaki, Kanagawa, 253, Japan (Present Address).
}

Radioactive nitrofen was absorbed and degraded thoroughly in rice and wheat, and the ${ }^{14} \mathrm{C}$ from nitrofen was reincorporated into glucose in grains and into lignin in stems and leaves. ${ }^{5,6)}$

In our previous study ${ }^{7-10)}$ the degradation of CNP in soils resulted in a fair amount of soilbound residue which was attributed to $\mathrm{CNP}$ $\mathrm{NH}_{2}$. In rice field surveys, ${ }^{11-13)}$ a small amount of the free $\mathrm{CNP}-\mathrm{NH}_{2}$ and a fair amount of the bound $\mathrm{CNP}-\mathrm{NH}_{2}$ were detected in soil, but neither $\mathrm{CNP}$ nor $\mathrm{CNP}-\mathrm{NH}_{2}$ were detected in rice grains.

In the present work, the absorption, translocation, and metabolism of $\mathrm{CNP}$ and $\mathrm{CNP}-$ $\mathrm{NH}_{2}$ in rice plants were studied by using ${ }^{14} \mathrm{C}-$ ring labeled compounds.

\section{MATERIALS AND METHODS}

\section{1. ${ }^{14} \mathrm{C}$-labeled and Non-labeled Chemicals}

The procedure for synthesizing nitrophenyl ring-labeled CNP will be reported elsewhere. ${ }^{10}$ ) The specific activity of $\mathrm{CNP}$ was $2.20 \mu \mathrm{Ci} / \mathrm{mg}$, 
and its radio-purity was $99.9 \%$.

2,4,6-Trichlorophenyl $\quad 4^{\prime}$-amino- ${ }^{14} \mathrm{C}$-phenyl ether was synthesized according to the following procedure. $320 \mathrm{mg}$ of nitrophenyl ring labeled ${ }^{14} \mathrm{C}-\mathrm{CNP}$ (specific activity, $1.10 \mu \mathrm{Ci}$ / $\mathrm{mg}), 1.0 \mathrm{~g}$ of $\mathrm{SnCl}_{2}, 3 \mathrm{ml}$ of ethanol, and 1 $\mathrm{ml}$ of conc. $\mathrm{HCl}$ in a round-bottom flask was refluxed for $2 \mathrm{hr}$. The reaction mixture was concentrated in vacuo. To the residue, $5 \mathrm{~N}-$ $\mathrm{NaOH}$ was added. After partition with benzene, the benzene solution was dehydrated with anhydrous sodium sulfate, concentrated to a suitable volume and purified by silicic acid column chromatography developed with benzene. The resulting compound had a specific activity of $1.22 \mu \mathrm{Ci} / \mathrm{mg}$, and a radio-purity of $99.0 \%$.

$N-[4-(2,4,6$ - Trichlorophenoxy)phenyl $]-\mathrm{D}-$ glucosylamine was synthesized from a mixture of $7.0 \mathrm{~g}$ of $\beta-\mathrm{D}-$ glucose and $5.7 \mathrm{~g}$ of $\mathrm{CNP}-\mathrm{NH}_{2}$ in $160 \mathrm{ml}$ of $95 \%$ aqueous ethanol, which was refluxed for $3 \mathrm{hr}$. After cooling, the precipitate was filtered, washed with ethanol, and recrystallized from 90\% ethanol. mp. 138-139.5 ${ }^{\circ} \mathrm{C}$, Calcd.: N, $3.11 \%, \mathrm{Cl}, 23.60 \%$, Found: N, $3.11 \%, \mathrm{Cl}, 22.99 \%$.

\section{Rice Plant}

Seeds of rice (Oryza sativa L., cv. Nihonbare) were germinated and allowed to grow in Kasugai's nutrient solution in a greenhouse. Seedlings at the three-leaf stage were harvested and treated with ${ }^{14} \mathrm{C}-\mathrm{CNP}$ or ${ }^{14} \mathrm{C}-\mathrm{CNP}-\mathrm{NH}_{2}$ according to the procedure which will be described later.

\section{Soil Sample}

A diluvial soil sample was collected in winter from the arable layer of a rice field at the Paddy Field Experimental Farm, Aichiken Agricultural Research Center in Anjo, Aichi Prefecture. Its properties were as follows: texture, light clay; water holding capacity, $53.5 \%, \mathrm{pH} 6.15$; total carbon, $1.75 \%$; total nitrogen, $0.15 \%$; cation exchange capacity, $9.99 \mathrm{meq} / 100 \mathrm{~g}$; clay mineral, kaoline; clay content, $45.2 \%$. The sample was crushed and passed through a $2 \mathrm{~mm}$ sieve.

\section{Absorption and Translocation of ${ }^{14} \mathrm{C}-$ Chemicals}

Seedlings of rice plant at the three-leaf stage were transferred into Kasugai's cultivating solution $(100 \mathrm{ml})$ containing $5 \mathrm{ppm}$ of ${ }^{14} \mathrm{C}-\mathrm{CNP}$ $\left(2.42 \times 10^{6} \mathrm{dpm}\right)$ or ${ }^{14} \mathrm{C}-\mathrm{CNP}-\mathrm{NH}_{2}\left(1.19 \times 10^{6}\right.$ $\mathrm{dpm})$. In the same manner, rice seedlings at the three-leaf stage were also transplanted into $100 \mathrm{~g}$ (dry weight basis) of soil in a $200-\mathrm{ml}$ beaker. Before the transplantation, this soil was mixed with ${ }^{14} \mathrm{C}-\mathrm{CNP}\left(4.84 \times 10^{6} \mathrm{dpm}\right)$ or ${ }^{14} \mathrm{C}-\mathrm{CNP}-\mathrm{NH}_{2}\left(2.38 \times 10^{6} \mathrm{dpm}\right)$ at $10 \mathrm{ppm}$ (dry soil basis) and submerged $1 \mathrm{~cm}$ deep, and allowed to stand for three days. These plants were allowed to grow under artificial light at 8,000-10,000 lux., for a 15-hr photoperiod at 20 to $30^{\circ} \mathrm{C}$. In water culture, the initial level of the nutrient solution was maintained by adding water periodically. The plant was harvested after designated intervals, washed successively with water and benzene to remove soil particles and radioactive chemicals adhering to the plant surface. The plant was divided into roots and foliage and the total radioactivity of each plant part was measured by the wet combustion method according to Kametani. ${ }^{14)}$

\section{Radioautogram}

Harvested plants washed according to the procedure described above were blotted with filter paper to remove excess benzene, spread out between two sheets of filter paper and pressed with hot iron. A X-ray film (Fuji Kx Medical, Fuji Photo Film Co., Ltd.) was exposed to the pressed plants for several weeks, and the resulting film was developed.

\section{Extraction and Fractionation}

Rice plants harvested at various intervals were washed by the same procedure as above and divided into foliage and roots. These samples were homogenized with $80 \%$ aqueous acetone and filtered. The fibrous residues were washed several times with $80 \%$ aqueous acetone. Then the filtrates were combined and diluted with acetone up to $100 \mathrm{ml}$. The radioactivity in the unextracted fibrous residue was determined by the wet combustion method. ${ }^{14}$ )

The combined filtrate was concentrated in vacuo to remove the solvent. The remaining aqueous phase was extracted with a total volume of $100 \mathrm{ml}$ of ether three times. The ether extracts were dried with anhydrous 
Table $1 R f$ values of $\mathrm{CNP}, \mathrm{CNP}-\mathrm{NH}_{2}$ and related compounds on silica gel thin layer chromatography.

\begin{tabular}{llcccc}
\hline \multirow{2}{*}{ Compounds } & \multicolumn{5}{c}{ Solvent system } \\
\cline { 2 - 6 } & \multicolumn{1}{c}{$\mathrm{A}$} & $\mathrm{B}$ & $\mathrm{C}$ & $\mathrm{D}$ & $\mathrm{E}$ \\
\hline $\mathrm{CNP}$ & 0.53 & 0.86 & 0.89 & - & - \\
$\mathrm{CNP}-\mathrm{NH}_{2}$ & 0.05 & 0.38 & 0.53 & 0.80 & 0.47 \\
Compound I & 0.00 & 0.12 & 0.28 & 0.73 & 0.12 \\
Compound II & 0.00 & 0.56 & 0.69 & 0.83 & 0.12 \\
Compound III & 0.03 & 0.44 & 0.55 & 0.70 & 0.05 \\
Compound IV & 0.00 & 0.09 & 0.21 & 0.79 & 0.10 \\
Unknown 1 & 0.62 & - & - & - & - \\
Unknown 2 & $*$ & 0.85 & - & - & - \\
Unknown 3 & $*$ & 0.90 & - & - & 0.00 \\
Glucoside & 0.00 & 0.00 & 0.00 & 0.60 & - \\
\hline
\end{tabular}

Solvent system: A, $n$-hexane-toluene $(3: 2)$; B, n-hexane-ethyl acetate $(5: 3)$; C, benzene-chloroform-acetone $(6: 3: 1)$; D, benzene-ethanol $(2: 1)$; E, benzene-Chloroform-diethylamine $(25: 25: 1)$.

Compound I, 2,4,6-trichlorophenyl 4'-formylaminophenyl ether; Compound II, 2,4,6trichlorophenyl 4'-hydroxyphenyl ether; Compound III, p-nitrophenol; Compound IV, 2,4,6-trichlorophenyl 4'-acetylaminophenyl ether; Glucoside, $N$-[4 (2,4,6-trichlorophenoxy)phenyl]-D-glucosylamine.

* In this solvent system these compounds did not give clear spots because of tailing.

sodium sulfate, and reduced to a suitable volume in vacuo. Then thin layer chromatog raphy was carried out on plates coated with silica gel $\mathrm{F}_{254}$ (E. Merck, precoated, $0.25 \mathrm{~mm}$ thick). The chromatograms were developed with the solvent systems shown in Table 1. An X-ray film was exposed to these chromatograms and developed.

The fibrous residue left after acetone extraction was refluxed for one hr with $3 \mathrm{~N} \mathrm{HCl}$. The mixture was filtered and the filtrate was shaken with ether. The degradation products in the ether extracts were separated and determined by thin layer chromatography as described above.

\section{Radioactivity Measurement}

Radioactivity extracted with the solvent was measured as follows: A small aliquot of the solvent was placed in a counting vial which contains $15 \mathrm{ml}$ of scintillation fluid (PPO $6 \mathrm{~g}$, POPOP $0.275 \mathrm{~g}$, and naphthalene $112 \mathrm{~g}$ in dioxane $1,000 \mathrm{ml}$ ).

The silica gel of each radioactive spot on the thin layer chromatogram was scraped into a counting vial containing the scintillation fluid.

The radioactivity of the fibrous residue left after acetone extraction was determined by the combustion method according to Kametani. ${ }^{14)}$ The ${ }^{14} \mathrm{CO}_{2}$ evolved from the burnt residue was trapped in $18 \mathrm{ml}$ of scintillation fluid $[\mathrm{PPO} 5 \mathrm{~g}$, POPOP $0.3 \mathrm{~g}, 1,000 \mathrm{ml}$ of ethanolamine : methylcellosolve : toluene (1: $3: 6)]$.

The radioactivity was measured using a Packard Model 3320-515 scintillation counter. All measurements were corrected for background and quenching. Counting efficiency for all samples was determined by the external standard technique.

\section{RESULTS AND DISCUSSION}

1. Absorption and Translocation of ${ }^{14} \mathrm{C}$ $\mathrm{CNP}$ and ${ }^{14} \mathrm{C}-\mathrm{CNP}-\mathrm{NH}_{2}$ in Rice Plants

The radioautograms of root-soaked rice plants indicated that the radioactivity in nutrient solution was absorbed into the roots, and was scarcely translocated to the upper parts, particularly in the case of $\mathrm{CNP}-\mathrm{NH}_{2}$ as shown in Fig. 1.

The distribution of radioactivity in the rice plant at various intervals after treating the roots with $\mathrm{CNP}$ and $\mathrm{CNP}-\mathrm{NH}_{2}$ is shown in Table 2. Absorption from water culture was apparently larger than from soil culture in all 


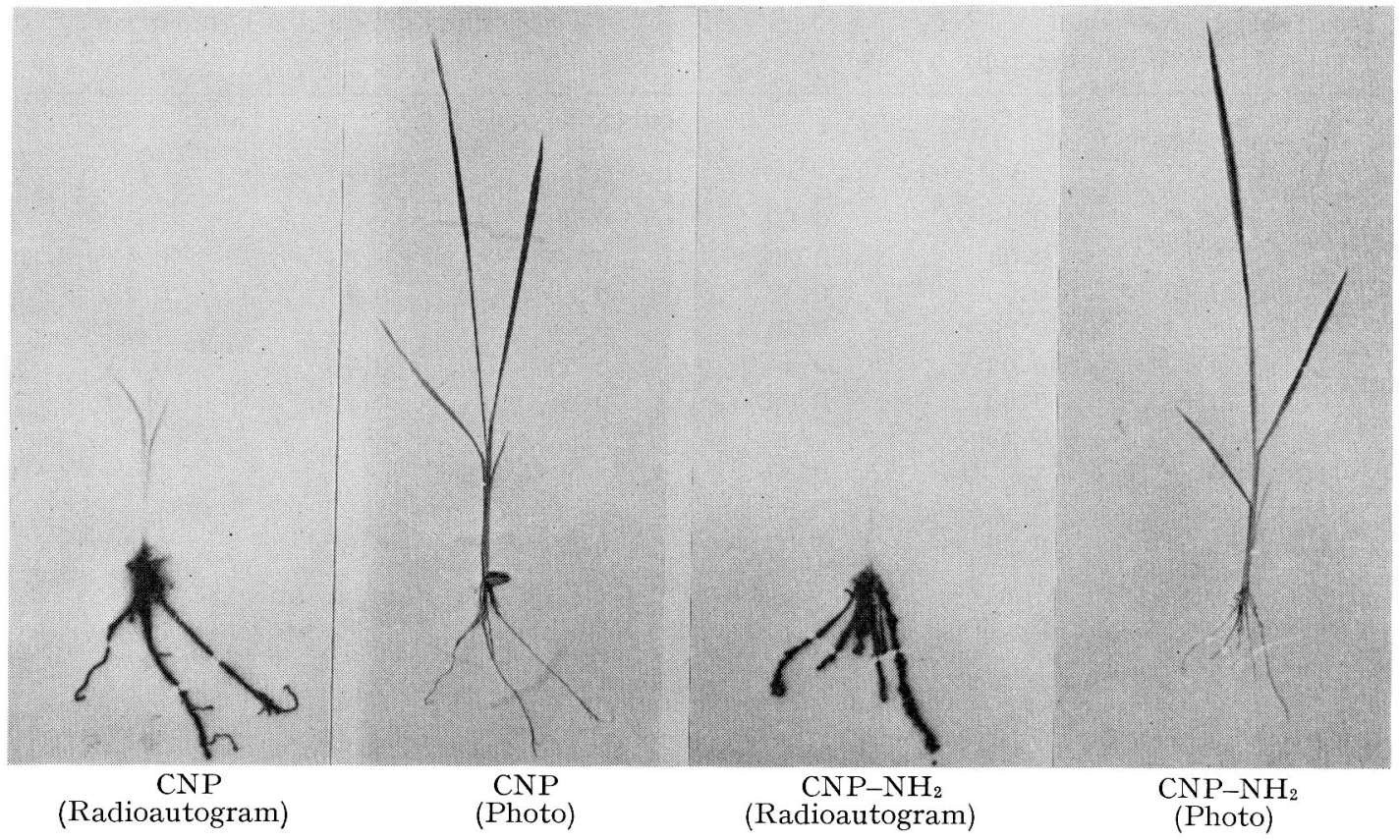

Fig. 1 Radioautograms and mounted plants showing the distribution of ${ }^{14} \mathrm{C}-\mathrm{CNP}$ (Left) and ${ }^{14} \mathrm{C}-\mathrm{CNP}-\mathrm{NH}_{2}$ (Right) in rice seedlings treated from the roots for 5 days.

Table 2 Absorption and transloction of the radioactivity in rice seedlings treated with ${ }^{14} \mathrm{C}-\mathrm{CNP}$ and ${ }^{14} \mathrm{C}-\mathrm{CNP}-\mathrm{NH}_{2}$.

\begin{tabular}{|c|c|c|c|c|c|}
\hline & & \multicolumn{2}{|c|}{ CNP treatment } & \multicolumn{2}{|c|}{$\mathrm{CNP}-\mathrm{NH}_{2}$ treatment } \\
\hline & & $\begin{array}{c}\text { Soil } \\
\text { culture }\end{array}$ & $\begin{array}{l}\text { Water } \\
\text { culture }\end{array}$ & $\begin{array}{c}\text { Soil } \\
\text { culture }\end{array}$ & $\begin{array}{l}\text { Water } \\
\text { culture }\end{array}$ \\
\hline \multirow[t]{2}{*}{$6 \mathrm{hr}$} & Roots & & 10,540 & & 8,830 \\
\hline & Foliage & & 880 & & 185 \\
\hline \multirow[t]{2}{*}{$24 \mathrm{hr}$} & Roots & & 19,330 & & 10,450 \\
\hline & Foliage & & 1,050 & & 230 \\
\hline \multirow[t]{2}{*}{5 days } & Roots & 3,990 & 25,070 & 463 & 14,590 \\
\hline & Foliage & 457 & 1,690 & 98 & 308 \\
\hline \multirow[t]{2}{*}{10 days } & Roots & 2,650 & 25,150 & 445 & 23,770 \\
\hline & Foliage & 537 & 1,610 & 138 & 421 \\
\hline \multirow[t]{2}{*}{20 days } & Roots & 1,860 & 33,280 & 410 & 23,580 \\
\hline & Foliage & 799 & 2,230 & 293 & 426 \\
\hline \multirow[t]{2}{*}{35 days } & Roots & 1,840 & & 418 & \\
\hline & Foliage & 860 & & 360 & \\
\hline
\end{tabular}

All numbers represent dpm per plant.

cases. The radioactivity in plants increased rapidly up to $24 \mathrm{hr}$ after the treatment, but subsequently increased only slightly. In soil culture, however, the radioactivity in plants did not increase after 5 days.

In water culture, $\mathrm{CNP}-\mathrm{NH}_{2}$ was a little more hardly absorbed by the roots than CNP, but its translocation to upper parts of the plant was markedly less than that of CNP. In soil culture, $\mathrm{CNP}-\mathrm{NH}_{2}$ was hardly absorbed by the plants. It seems because $\mathrm{CNP}-\mathrm{NH}_{2}$ is strongly adsorbed on soil particles. ${ }^{8}$ The difference in the absorption of $\mathrm{CNP}$ and $\mathrm{CNP}$ $\mathrm{NH}_{2}$ by rice roots may be owing to the difference in water solubility of these chemicals (CNP $0.3 \mathrm{ppm}$, and $\mathrm{CNP}-\mathrm{NH}_{2} 2.7 \mathrm{ppm}$ at 
Table 3 Distribution of radioactivity in rice plants treated with ${ }^{14} \mathrm{C}-\mathrm{CNP}$.

\begin{tabular}{ccccccccc}
\hline & & \multicolumn{3}{c}{ Roots } & & \multicolumn{3}{c}{ Foliage } \\
\cline { 8 - 9 } \cline { 7 - 8 } & Days & $\begin{array}{c}\text { Ether } \\
\text { extracts }\end{array}$ & $\begin{array}{c}\text { Aqueous } \\
\text { remainings }\end{array}$ & $\begin{array}{c}\text { Fibrous } \\
\text { residue }\end{array}$ & & $\begin{array}{c}\text { Ether } \\
\text { extracts }\end{array}$ & $\begin{array}{c}\text { Aqueous } \\
\text { remainings }\end{array}$ & $\begin{array}{c}\text { Fibrous } \\
\text { residue }\end{array}$ \\
\hline Soil & 5 & 75.7 & 3.4 & 12.1 & & 7.8 & 0.5 & 0.7 \\
culture & 10 & 63.8 & 2.2 & 12.8 & & 12.6 & 1.6 & 1.0 \\
& 20 & 47.7 & 3.0 & 16.9 & & 23.7 & 2.1 & 1.7 \\
& 35 & 41.4 & 3.4 & 31.8 & & 19.7 & 1.5 & 1.2 \\
\hline Water & 5 & 89.2 & 0.6 & 1.9 & & 5.9 & 0.4 & 0.1 \\
culture & 10 & 86.5 & 2.0 & 3.7 & & 4.6 & 0.6 & 0.2 \\
& 20 & 86.3 & 2.1 & 4.6 & & 5.7 & 0.5 & 0.3 \\
\hline
\end{tabular}

All numbers represent the percentage of radioactivity of each fraction based on the total radioactivity in plants.

Table 4 Distribution of radioactivity in rice plants treated with ${ }^{14} \mathrm{C}-\mathrm{CNP}-\mathrm{NH}_{2}$.

\begin{tabular}{crccccccc}
\hline & & \multicolumn{3}{c}{ Roots } & & \multicolumn{3}{c}{ Foliage } \\
\cline { 8 - 9 } \cline { 7 - 8 } & Days & $\begin{array}{c}\text { Ether } \\
\text { extracts }\end{array}$ & $\begin{array}{c}\text { Aqueous } \\
\text { remainings }\end{array}$ & $\begin{array}{c}\text { Fibrous } \\
\text { residue }\end{array}$ & $\begin{array}{c}\text { Ether } \\
\text { extracts }\end{array}$ & $\begin{array}{c}\text { Aqueous } \\
\text { remainings }\end{array}$ & $\begin{array}{c}\text { Fibrous } \\
\text { residue }\end{array}$ \\
\hline Soil & 5 & 48.2 & 4.8 & 22.4 & & 9.5 & 4.3 & 2.0 \\
culture & 10 & 39.7 & 10.2 & 27.1 & & 8.7 & 9.9 & 2.2 \\
& 20 & 29.3 & 6.3 & 19.3 & & 23.7 & 9.8 & 5.6 \\
& 35 & 34.6 & 9.5 & 24.7 & & 19.1 & 4.9 & 6.0 \\
\hline Water & 5 & 61.1 & 6.0 & 30.0 & & 1.2 & 0.5 & 0.2 \\
culture & 10 & 68.5 & 3.1 & 23.0 & & 1.2 & 0.3 & 0.1 \\
& 20 & 74.3 & 2.0 & 19.6 & & 1.0 & 0.6 & 0.2 \\
\hline
\end{tabular}

All numbers represent the percentage of radioactivity of each fraction based on the total radioactivity in plants.

$\left.26^{\circ} \mathrm{C}\right)$.

The aqueous acetone solution extracted from the plants was concentrated, and the radioactive substances were partitioned into ether and water. The distribution of the radioactivity in these fractions, for plants treated with CNP, is shown in Table 3. Most of the radioactivity absorbed by plants from water culture was extracted with aqueous acetone, and the unextractable radioactivity in fibrous residue gradually increased with the lapse of time. In soil culture, a large portion of the radioactivity absorbed by roots was unextractable with aqueous acetone. Most of the radioactivity in the aqueous acetone extracts was extractable with ether, particularly in the extracts from the roots.

The distribution of radioactivity in each fraction, for plants treated with $\mathrm{CNP}-\mathrm{NH}_{2}$, is shown in Table 4. In the case of water culture, the radioactivity in the water fraction after partition with ether and in the fibrous residue obtained from $\mathrm{CNP}-\mathrm{NH}_{2}$ treated plants was in contrast with that from CNP-treated plants. In soil culture, a large part of the radioactivity in plants was unextractable, and the radioactivity in the aqueous acetone extracts was hardly extractable with ether.

In water culture, it is thought that $\mathrm{CNP}$ $\mathrm{NH}_{2}$ absorbed into roots was readily bound with tissue constituents such as lignin, and consequently the radioactivity in plants became hardly extractable with aqueous acetone and could not be partitioned with ether. On the other hand, CNP was hardly degraded in the plants but it may not be bound with these tissue constituents. This may be the reason why the radioactivity absorbed by roots was readily extracted with aqueous acetone. The rate of translocation of $\mathrm{CNP}-\mathrm{NH}_{2}$ to the upper 
parts of plants was less than that of CNP. This tendency may be attributed to the formation of complexes with plant materials.

In soil culture, a portion of the degradation products of $\mathrm{CNP}$ formed in soil was absorbed by the roots, and a larger portion of unextractable radioactivity remained in the fibrous residue in soil culture than in water culture. These may also be because of the easy binding of $\mathrm{CNP}-\mathrm{NH}_{2}$ with tissue constituents of plants. A very small amount of the radioactivity was translocated to the upper parts, but the radioactivity corresponded with 10 to $40 \%$ of the absorbed amount. A large portion of this radioactivity may be attributed to the degradation products of $\mathrm{CNP}$ or $\mathrm{CNP}-\mathrm{NH}_{2}$ in soil which were absorbed by roots and translocated to the foliage.

\section{Metabolism of ${ }^{14} \mathrm{C}-\mathrm{CNP}$ and ${ }^{14} \mathrm{C}-\mathrm{CNP}$ - $\mathrm{NH}_{2}$ in Rice Plants}

Metabolites in the ether fraction were identified by the radioautographic technique. Radioautograms of the ether extracts obtained from the roots treated with $\mathrm{CNP}$ revealed the presence of CNP, compound I (2,4,6-trichlorophenyl 4'-formylaminophenyl ether), compound II (2,4,6-trichlorophenyl 4'-hydroxyphenyl ether), and an unidentified compound (unknown I). However, the amounts of these metabolites were very small as shown in Table 5. No phenolic metabolite derived by cleavage of the ether linkage of $\mathrm{CNP}$ was detected, in contrast to fluorodifen, a dephenyl ether herbicide. ${ }^{2)}$ In water culture, CNP was scarcely metabolized in rice plants, and 77.2 to $84.7 \%$ of the radioactivity absorbed by plants was recovered as CNP. A small amount of $\mathrm{CNP}-\mathrm{NH}_{2}$ conjugated with glucose, i.e., $N$-[4-(2,4,6-trichlorophenoxy)phenyl]-D-glucosylamine was found in the ether fraction by co-chromatography with the synthetic compound. A proposed metabolic pathway of $\mathrm{CNP}$ in rice plants is shown in Fig. 2. The compound I, $\mathrm{N}$-formyl derivative of $\mathrm{CNP}-\mathrm{NH}_{2}$ was found, but $\mathrm{CNP}-\mathrm{NH}_{2}$ itself was not detected in the ether extracts. The hydrolysate of the fibrous residue revealed a small amount of $\mathrm{CNP}-\mathrm{NH}_{2}$.

In soil culture, the percentage of the unchanged $\mathrm{CNP}$ in the absorbed radioactivity was less than in water culture, and the relatively large amount of degradation products appeared in a aqueous acetone extracts. Some of these degradation products recovered from the plants under soil culture were not found in those under water culture. Therefore, it seemed that some of these degradation products were formed in these soil and taken up by the plants. These compounds were grouped under the heading "others" in Table 5. As CNP present in the soil was degraded, the amount of CNP in roots gradually decreased. About $10 \%$ of the added radioactivity was recovered as ${ }^{14} \mathrm{C}-\mathrm{CNP}$ from the soil 35 days after the treatment. The unchanged $\mathrm{CNP}$ in the roots

Table $5 \mathrm{CNP}$ and its metabolites in the ether extracts.

\begin{tabular}{|c|c|c|c|c|c|c|c|c|}
\hline \multirow{2}{*}{ Metabolites } & & \multicolumn{3}{|c|}{ Water culture } & \multicolumn{4}{|c|}{ Soil culture } \\
\hline & & 5 & 10 & 20 days & 5 & 10 & 20 & 35 days \\
\hline \multirow[t]{2}{*}{$\mathrm{CNP}$} & $\mathrm{R}$ & 84.7 & 77.2 & 79.1 & 63.8 & 42.6 & 20.9 & 20.0 \\
\hline & $\mathrm{F}$ & 5.8 & 4.2 & 5.3 & 7.6 & 11.9 & 21.7 & 17.9 \\
\hline \multirow[t]{2}{*}{ Compounds I } & $\mathrm{R}$ & 0.6 & 1.6 & 1.3 & 1.4 & 4.0 & 4.6 & 2.2 \\
\hline & $\mathrm{F}$ & 0.0 & 0.1 & 0.1 & 0.0 & 0.1 & 0.0 & 0.0 \\
\hline \multirow[t]{2}{*}{ Compounds II } & $\mathrm{R}$ & 0.4 & 0.6 & 0.5 & 0.7 & 1.1 & 2.1 & 1.5 \\
\hline & $\mathrm{F}$ & 0.0 & 0.0 & 0.0 & 0.0 & 0.0 & 0.0 & 0.3 \\
\hline \multirow[t]{2}{*}{ Unknown 1} & $\mathrm{R}$ & 0.5 & 0.8 & 0.7 & 0.0 & 0.0 & 0.0 & 0.0 \\
\hline & $\mathrm{F}$ & 0.0 & 0.0 & 0.0 & 0.0 & 0.0 & 0.0 & 0.0 \\
\hline \multirow{2}{*}{$\begin{array}{l}\text { Original } \\
\text { region }\end{array}$} & $\mathrm{R}$ & 1.4 & 3.4 & 2.4 & 3.3 & 7.7 & 10.0 & 5.3 \\
\hline & $\mathrm{F}$ & 0.1 & 0.2 & 0.2 & 0.1 & 0.4 & 1.6 & 0.6 \\
\hline \multirow[t]{2}{*}{ Others } & $\mathrm{R}$ & 1.5 & 2.9 & 2.2 & 3.5 & 8.4 & 10.2 & 12.5 \\
\hline & $\mathrm{F}$ & 0.0 & 0.1 & 0.1 & 0.0 & 0.1 & 0.4 & 0.9 \\
\hline
\end{tabular}

All numbers represent the percentage of radioactivity of each metabolite based on the total radioactivity in plants. F, Foliage; $\mathrm{R}$, Roots. 
was $20 \%$ of the total radioactivity absorbed by the plants at this stage. The amount of unchanged CNP was $79 \%$ of the total radioactivity translocated to the foliage and $91 \%$ of the radioactivity in its ether extracts. $\mathrm{CNP}_{-}$ $\mathrm{NH}_{2}$, the main degradation product of CNP in soil, is strongly adsorbed on soil particles to form complexes with soil organic matter. ${ }^{9)}$ Therefore, most of these were hardly absorbed by the plants. CNP which is not adsorbed virtually by soil particles was absorbed by the plants.

When the fibrous residue of roots left after aqueous acetone extraction was hydrolyzed with hydrochloric acid, about 75 to $87 \%$ of the radioactivity in the residue was extracted with ether as shown in Table 7. CNP is not changed virtually under these conditions. A fair number of the degradation products appeared in the ether extracts of the hydrolysate. Fair amounts of compound I and an unknown compound were found, accompanied by small amounts of $\mathrm{CNP}$ and $\mathrm{CNP}-\mathrm{NH}_{2}$. Free $\mathrm{CNP}-\mathrm{NH}_{2}$ was not found in the ether extracts from roots but was found after hydrolysis. These compounds, for the most part, seemed to be bound with tissue constituents, mainly lignin, and are thus unextractable unless the tissue are hydrolyzed with hydrochloric acid.
$\mathrm{CNP}-\mathrm{NH}_{2}$ was readily absorbed by rice plants from water, but it was not translocated to the upper parts, as it was not detected in the foliage, as shown in Table 6 . In water culture, $\mathrm{CNP}-\mathrm{NH}_{2}$ was readily metabolized by the rice plants in contrast to $\mathrm{CNP}$, and only trace amounts of $\mathrm{CNP}-\mathrm{NH}_{2}$ was detected in the roots, and was not detected at all in the foliage. Most of these metabolites of $\mathrm{CNP}_{-}$ $\mathrm{NH}_{2}$ in rice plants have not been identified. The main metabolites were unknown 2 and unknown 3, which were formed one hour after treatment with $\mathrm{CNP}-\mathrm{NH}_{2}$. Compound $\mathrm{I}$ and compound II were present in small amounts. Unknown 2 and unknown 3 which were formed from $\mathrm{CNP}-\mathrm{NH}_{2}$ bound to the plant tissues, were presumed to be less polar compounds, based on their chromatographic behavior.

Hydrolysates of the fibrous residue of plants treated with $\mathrm{CNP}-\mathrm{NH}_{2}$ provided fair amounts of two hydrolytic products described as unknown in Table 7, but these were not identified. These products were similarly formed by refluxing of the $\mathrm{CNP}-\mathrm{NH}_{2}$ with rice plants in dil. hydrochloric acid, in the same manner as described above. Therefore, these unknwon products may be artifacts arising from $\mathrm{CNP}$ $\mathrm{NH}_{2}$ bound to plant tissues.

These results are summarized as follows:

Table 6 CNP-NH$H_{2}$ and its metabolites in the ether extracts.

\begin{tabular}{|c|c|c|c|c|c|c|c|c|}
\hline \multirow{2}{*}{ Metabolites } & & \multicolumn{3}{|c|}{ Water culture } & \multicolumn{4}{|c|}{ Soil culture } \\
\hline & & 5 & 10 & 20 days & 5 & 10 & 20 & 35 days \\
\hline \multirow[t]{2}{*}{$\mathrm{CNP}-\mathrm{NH}_{2}$} & $\mathrm{R}$ & 1.7 & 1.6 & 1.6 & 3.3 & 2.5 & 1.1 & 1.8 \\
\hline & $\mathrm{F}$ & 0.0 & 0.0 & 0.0 & & & & \\
\hline \multirow[t]{2}{*}{ Compound I } & $\mathrm{R}$ & 8.9 & 3.1 & 2.1 & 5.2 & 5.8 & 2.7 & 2.0 \\
\hline & $\mathrm{F}$ & 0.2 & 0.1 & 0.1 & & & & \\
\hline \multirow[t]{2}{*}{ Compound II } & $\mathrm{R}$ & 2.0 & 1.7 & 2.2 & 2.0 & 2.0 & 1.1 & 1.1 \\
\hline & $\mathrm{F}$ & 0.1 & 0.0 & 0.0 & & & & \\
\hline \multirow[t]{2}{*}{ Unknown 2} & $\mathrm{R}$ & 7.0 & 19.3 & 22.1 & 0.0 & 0.0 & 0.0 & 0.0 \\
\hline & $\mathrm{F}$ & 0.0 & 0.0 & 0.0 & & & & \\
\hline \multirow[t]{2}{*}{ Unknown 3} & $\mathrm{R}$ & 11.7 & 24.1 & 28.5 & 16.1 & 13.3 & 10.8 & 15.6 \\
\hline & $\mathrm{F}$ & 0.7 & 0.8 & 0.5 & & & & \\
\hline \multirow[t]{2}{*}{ Unknown 4} & $\mathrm{R}$ & 0.0 & 0.0 & 0.0 & 2.7 & 3.3 & 2.1 & 1.1 \\
\hline & $\mathrm{F}$ & 0.0 & 0.0 & 0.0 & & & & \\
\hline \multirow{2}{*}{$\begin{array}{r}\text { Original } \\
\text { region }\end{array}$} & $\mathrm{R}$ & 17.2 & 9.0 & 8.2 & 9.9 & 10.9 & 5.9 & 6.0 \\
\hline & $\mathrm{F}$ & 0.2 & 0.2 & 0.3 & & & & \\
\hline \multirow[t]{2}{*}{ Others } & $\mathrm{R}$ & 12.9 & 9.9 & 9.8 & 9.1 & 8.6 & 5.6 & 7.1 \\
\hline & $\mathrm{F}$ & 0.1 & 0.1 & 0.1 & & & & \\
\hline
\end{tabular}

All numbers represent the percentage of radioactivity of each metabolite based on the total radioactivity in plants. F, Foliage; R. Roots. 
Table 7 Ether-extractable metabolites in hydrolysate of the fibrous residue of roots with $3 \mathrm{~N} \mathrm{HCl}$.

\begin{tabular}{|c|c|c|c|c|c|c|c|}
\hline \multicolumn{4}{|c|}{ CNP treatment } & \multicolumn{4}{|c|}{$\mathrm{CNP}-\mathrm{NH}_{2}$ treatment } \\
\hline Metabolites & 5 & 10 & 20 days & Metabolites & 5 & 10 & 20 days \\
\hline $\mathrm{CNP}$ & 2.8 & 0.6 & 0.7 & $\mathrm{CNP}-\mathrm{NH}_{2}$ & 1.3 & 2.0 & 4.6 \\
\hline $\mathrm{CNP}-\mathrm{NH}_{2}$ & 1.9 & 3.0 & 2.0 & Unknown & 77.5 & 75.4 & 68.7 \\
\hline Compound I & 5.8 & 15.8 & 13.0 & Others & 3.4 & 1.4 & 1.4 \\
\hline Unknown & 21.1 & 10.9 & 6.4 & Original & 4.3 & 6.6 & 9.7 \\
\hline Others & 36.7 & 23.8 & 21.5 & Total & 86.6 & 85.3 & 84.4 \\
\hline Original & 7.4 & 32.4 & 34.7 & & & & \\
\hline Total & 75.8 & 36.6 & 78.4 & & & & \\
\hline
\end{tabular}

All numbers represent the percentage of radioactivity of each metabolite based on the total radioactivity of the fibrous residue.

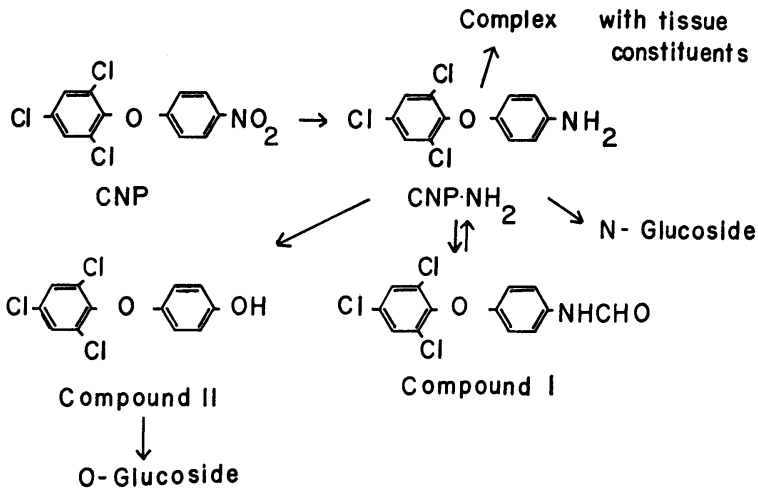

Fig. 2 Proposed metabolic pathway of CNP in plant.

$\mathrm{CNP}$ and its amino derivative (CNP- $\left.\mathrm{NH}_{2}\right)$ were absorbed into the roots of rice plants in water culture, but these compounds, especially $\mathrm{CNP}-\mathrm{NH}_{2}$ were hardly transferred to the upper parts of the plants. In soil culture, however, the absorption of $\mathrm{CNP}-\mathrm{NH}_{2}$ by the plants was extremely limited due to the strong adsorption on soil particles. In plants, CNP was slowly metabolized to form $\mathrm{CNP}-\mathrm{NH}_{2}$ and $\mathrm{CNP}-\mathrm{OH}$ and their glycosides. The cleavage of ether linkage hardly occurred. These results may indicate that in paddy field rice plants absorb a small amount of CNP herbicide and almost no $\mathrm{CNP}-\mathrm{NH}_{2}$, although fair amounts of $\mathrm{CNP}-$ $\mathrm{NH}_{2}$ are formed and retain for rather long period in flooded soil as the conjugate form.

\section{ACKNOWLEDGEMENT}

We are indebted to Mr. T. Yoshimoto, Research Center, Mitsui-Toatsu Chemicals Inc., for providing us with radioactive $\mathrm{CNP}$ and many authentic chemicals.

\section{REFERENCES}

1) D. Hawton \& E. H. Stobbe: Weed Sci. 19, 555 (1971)

2) R. L. Rogers: J.Agric. Food Chem. 19, 32 (1971)

3) D. R. Frear \& H. P. Swanson: Pestic. Biochem. Physiol. 3, 473 (1973)

4) Y. Niki, S. Kuwatsuka \& I. Yokomichi: Agric. Biol. Chem. 40, 683 (1976)

5) J. P. Wargo, R. C. Honeycutt \& I. L. Adler: J. Agric. Food Chem. 23, 1095 (1975)

6) R. C. Honeycutt \& I. L. Adler: ibid. 23, 1097 (1975)

7) S. Kuwatsuka: "Environmental Toxicology of Pesticides," ed. by F. Matsumura, G. M. Boush \& T. Misato, Academic Press, New York and London, p. 385, 1972

8) H. Shimotori \& S. Kuwatsuka: Abstracts of Ann. Meeting of Agric. Chem. Soc. Japan, p. 26 (1975)

9) H. Shimotori \& S. Kuwatsuka: Abstracts of Ann. Meeting of Pestic. Sci. Soc. Japan, p. 222 (1976)

10) H. Shimotori, S. Kuwatsuka \& T. Yoshimoto: J. Pesticide Sci. under preparation

11) T. Yamada, H. Nakamura \& S. Matsunaka: Abstracts of Ann. Meeting of the Agric. Chem. Soc. of Japan, p. 444 (1974)

12) T. Yamada: Abstracts of Ann. Meeting of the Weed Sci. Soc. of Japan, p. 117 (1975)

13) T. Toyama \& S. Tamagawa: Noyaku Kagaku (J. Pesticide Sci.) 3, 178 (1976)

14) K. Kametani, Y. Inoue \& K. Maruyama: Radioisotopes 16, 41 (1967) 
要 約

CNP およびそのアミノ体のイネ体における吸 収, 移行, 代謝

下鳥 均, 鏉塚昭三 ジフェニルェーテル系除草郕 CNP およびその土塞中 における主生成物であるアミノ体 $\left(\mathrm{CNP}-\mathrm{NH}_{2}\right)$ のイネ 体に抢ける吸収, 移行, 代謝について, ベンゼン環標識 ${ }^{14} \mathrm{C}$ 化合物を用い, 室内実験により研究した。両化合物 とも水耕液から速やかに根に吸収されるが, 地上部への 移行はきわめて少なく，とくにアミノ体はほとえど移行
しなかった。土堙からの吸収は水耕液からの吸収よりも はるかに少なかった、イネ体内に打ける CNPの代謝は きかめて遅いが， $\mathrm{CNP}-\mathrm{NH}_{2}$ は速やかに代謝された。 CNP の主代謝物として 3 種類の化合物が検出され，そ のうちの 2 種類を CNP のニトロ基がホルミルアミノ 基および水酸基に変換された化合物と同定した．そのほ かに CNP-NH $\mathrm{N}_{2}$ およびその $N$-glucoside も検出され た。水耕液からイネ体内に吸収された $\mathrm{CNP}-\mathrm{NH}_{2}$ は速 やかに減少し， 2 種類の主生成物のほかに多数の代謝物 が検出された。 